УДК 330.3:332

DOI: 10.25140/2411-5215-2020-1(21)-151-159

\author{
Аліна Дідовеиь
}

\title{
ТЕОРЕТИКО-МЕТОДОЛОГІЧНІ АСПЕКТИ ВІДТВОРЕННЯ ПРОДУКТИВНИХ СИЛ В УМОВАХ СВРОІНТЕГРАЦІї
}

\author{
Алина Дидовеи \\ ТЕОРЕТИКО-МЕТОДОЛОГИЧЕСКИЕ АСПЕКТЫ ВОСПРОИЗВОДСТВА \\ ПРОДУКТИВНЫХ СИЛ В УСЛОВИЯХ ЕВРОИНТЕГРАЦИИ
}

\author{
Alina Didovets
}

\section{THEORETICAL-METHODOLOGICAL ASPECTS OF THE PRODUCTION FORCE REPRODUCTION IN THE EUROPEAN INTEGRATION CONDITIONS}

У статті узагальнено науковий матеріал з досліджуваної теми, обтрунтовано ідею про те, щзо вирішальною умовою економічного та сочіального зростання країни є відтворення продуктивних сил, від територіальних особливостей, стану та характеру розвитку яких залежить сучасний розвиток усіх регіонів Украӥни. Розкрито категоріально-змістовну характеристику поняття «продуктивні сили», під якими розуміємо сукупність людських, матеріальних та інших силових елементів, з притаманною їм утворюючою дією, які беруть участь у продукуванні засобів, забезпеченні умов існування людини, соціального прогресу та самовідтворювальної здатності природи й суспільства, але з урахуванням принципу оздоровлення екологічної ситуації, щзо вимагатиме екологізації свідомості, законодавства, управління. Наведено принципи розміщення продуктивних сил, серед яких: раціональне та комплексне розміщення виробництва, збалансованість та пропориійність розміщення виробництва, внутрішньодержавний та міжнародний поділ праці, обмежений иентралізм. Доведено, щзо процес глобалізації світової економіки створює потребу євроінтеграційного розвитку Украӥни, щуо, у свою чергу, сприятиме радикальним перетворенням на шляху підвищення рівня сочіально-економічного розвитку демократичної держави та відтворенню продуктивних сил через відновлення всіх факторів виробництва.

Ключові слова: продуктивні сили; відтворення; євроінтеграція; сталий розвиток; закономірності; принципи; екологізація.

Рис.: 1. Бібл.: 16

В статье обобщен научный материал по исследуемой теме, обоснованно идею о том, что решающим условием экономического и сочиального роста страны является воспроизведение производительньх сил, от территориальных особенностей, состояния и характера развития которых зависит современное развитие всех регионов Украины. Раскрыто категориально-содержательную характеристику понятия «производительные сильл», под которыми понимаем совокупность человеческих, материальных и других силовых элементов, с присущчим им образующим действием, которые участвуют в продуциировании средств, обеспечении условий существования человека, социального прогресса и само воспроизводительной способности природы и общества, но с учетом приниипа оздоровления экологической ситуачии, что потребует экологизачии сознания, законодательства, управления. Приведень приниипьл размещения производительных сил, среди которых: раџиональное и комплексное размещение производства, сбалансированность и пропорииональность размечения производства, внутригосударственное и международное разделение труда, ограниченный ияентрализм. Доказано, что прочеесс глобализации мировой экономики создает потребность евро интеграционного развития Украины, что в свою очередь приведет к радикальнылм преобразованиям на пути повышения уровня сочиально-экономического развития демократического государства и воспроизводству производительных сил через восстановление всех факторов производства.

Ключевые слова: продуктивные силь; воспроизводство; эвроинтеграция; устойчивое развитие; закономерности; принцииь; экологизацчия

Pис.: 1. Библ.: 16.

The article summarizes the scientific material on the topic, substantiates the idea that the decisive condition for economic and social growth of the country is the reproduction of productive forces, the territorial features, condition and nature of which depend on the modern development of all regions of Ukraine. The categorical and meaningful characteristic of the concept of "productive forces» is understood, by which we understand the totality of human, material and other force elements, with their inherent forming effect, which are involved in the production of means, maintenance of the conditions of human existence, social progress and self-reproductive capacity of nature, and social community, but taking into account the principle of improving the environmental situation, which will require the greening of consciousness, legislation, management. The principles of allocation of productive forces are given, among them: rational and complex placement of production, balance and proportionality of distribution of production, domestic and international division of labor, limited centralism. It is proved that the process of globalization of the world economy creates the need for European integration of Ukraine, which, in turn, will contribute to radical transformations in the way of increasing the level of socio-economic development of a democratic state and the restoration of productive forces through the restoration of all factors of production.

Keywords: productive forces, reproduction, European integration, sustainable development, laws, principles, greening

Fig.: 1. References: 16.

JEL Classification: R12; L52

(С) Дідовець А. С., 2020 
ПРОБЛЕМИ МЕНЕДЖМЕНТУ ТА РОЗВИТКУ ПРОДУКТИВНИХ СИЛ РЕГІОНУ

Постановка проблеми. На структурну трансформацію національного господарства України на засадах сталого розвитку суттєво впливає наявний потенціал розширеного відтворення ресурсної бази соціально-економічного піднесення на інституціональній та технологічній основі. Як свідчить європейський досвід та аргументовані результати структурної перебудови переважної більшості сегментів національного господарства, акумулювання потенціалу (природноресурсного, рекреаційного, демографічного, соціально-культурного, виробничого, науково-технічного та інформаційного) створить передумови для формування та покращення напрямів забезпечення сталого розвитку держави та окремих регіонів $[11 ; 15]$. У зв'язку з цим особливого значення набувають питання подальшого розвитку продуктивних сил в економіці країни з урахуванням теоретичного спадку, накопиченого економічною наукою протягом її історичного розвитку, посилення нестійкості економіки й поглиблення нерівномірності розвитку у зв'язку з процесами глобалізації та євроінтеграції, які є основоположними питаннями для визначення майбутнього вектору розвитку центральноєвропейських країн, включаючи Україну [16].

У свою чергу, міжрегіональну економічну інтеграцію треба розглядати як зближення, взаємопроникнення і зрощення відтворювальних процесів суб'єктів господарювання двох і більше регіонів, що перетворює їх на цілісний господарський механізм, на міжрегіональну економічну систему, яка виступає складовою єдиного національного економічного простору [13].

Отже, можна сказати, що відтворення продуктивних сил є вагомою умовою економічного й соціального піднесення країни, стан, характер розвитку та територіальна особливість яких впливатиме на нинішній розвиток кожного регіону України, особливо в умовах посилення кризових явищ, що впливають на системність продуктивних сил $\mathrm{i}$ актуалізують об'єктивну необхідність пошуку механізмів регулювання та розвитку процесів їх відтворення. Вищезазначене зумовлює обраний напрям дослідження з урахуванням розуміння теоретичних витоків та засад сучасних наукових поглядів на визначення категорії «продуктивні сили».

Аналіз останніх досліджень та публікацій. Проблеми розвитку та модернізації продуктивних сил розглядаються в роботах вітчизняних та закордонних учених, таких як А. Вебер, В. Вернадський, Ф. Ліст, Д. Рікардо, М. Туган-Барановський, I. Тюнен, О. Бєляєв, С. Мочерний, В. Савчук та ін. Продуктивні сили з позиції регіональної економіки розглянуті в працях таких вітчизняних науковців: О. Амоша, Б. Буркинський,

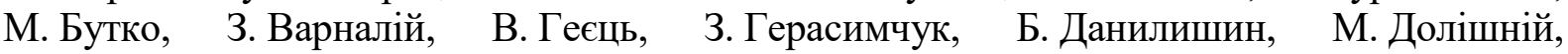
С. Дорогунцов, В. Захарченко, Ю. Макогон, В. Мельник, В. Мікловда, Н. Мікула, В. Пила, М. Тимчук, Л. Чернюк, М. Чумаченко, А. Шевчук та ін. Віддаючи належне детальному вивченню проблем відтворення продуктивних сил в наукових працях зазначених учених, вважаємо за необхідне окремі аспекти теоретичного та методологічного змісту поглибити та обгрунтувати з урахуванням актуалізації цього напряму дослідження.

Формування цілей статті. Враховуючи глибокі наукові напрацювання 3 цієї проблеми, визначаємо розкриття сутності та змісту досліджуваного поняття, а саме «продуктивні сили», як сукупності людських та інших силових елементів із притаманною їм суттєвою властивістю утворюючого характеру, головною метою цієї роботи. Мета зумовила конкретні завдання, а саме: розкрити категоріально-змістовну характеристику поняття «продуктивні сили»; порівняти погляди щодо сутності досліджуваного поняття; узагальнити принципи та закономірності розвитку й розміщення продуктивних сил; дослідити вплив євроінтеграції на процеси відтворення продуктивних сил.

Виклад основного матеріалу. 3 урахуванням того, що ефективність дослідження економічною наукою питань розміщення продуктивних сил датована кінцем XIX ст., самої теорії розміщення продуктивних сил на той час ще не було. Однак розквіт економічної науки відбувся через продукування засад ринкової теорії розміщення виробництва, а не тіль- 
ПРОБЛЕМИ МЕНЕДЖМЕНТУ ТА РОЗВИТКУ ПРОДУКТИВНИХ СИЛ РЕГІОНУ

ки внаслідок аналізу й узагальнення. У той час у всій повноті утворюється практичне завдання позиціювання великого виробництва, вибору району, який найбільше відповідає певним умовам та вимогам щодо джерел енергії, сировини, робочої сили, ринків збуту.

3 урахуванням значного внеску У. Ізарда, А. Вебера, А. Гетнера, А. Льоша, Й. Тюнена, В. Крісталлера, П. Хаггета, Дж. Чорлі в розроблення методологічних основ науки про розміщення продуктивних сил, дослідження теорії розміщення виробництва А. Вебером та Й. Тюненом (кін. XVIII - поч. XIX ст.) вважають передумовою розвитку теорії продуктивних сил. Під продуктивними силами, у свою чергу, вони розуміли кінцевий результат просторового розподілу залишку сільськогосподарської продукції продовольчого та сировинного використання для робітників та виробництва.

Модель Й. Тюнена, яка сприймалася у свій час як класична модель розміщення сільського господарства, була презентована у 1826 р. працею «Ізольована держава (Der Isolierte Staat in Beziehung auf Landwirtschaft und Nationaloekonomie)». Цю модель економісти пізнішого періоду (К. Гувер (1935), А. Льош (1954) та інші) використовували за основу нормативних моделей, незважаючи на іiі описовість за характером викладу. На сьогодні розвиток транспорту та виникнення нової техніки фундаментально змінили схему розміщення виробництва розроблену Йоганном Тюненом, однак деякі закордонні вчені вважають доцільним використовувати цю модель в окремих випадках ще й у наші дні. Більш вдале обрання місця виробництва перетворилося на вагому передумову отримання додаткової вартості. Враховуючи, що певні території різняться запасами як мінерально-сировинних, так і паливно-енергетичних, водних та трудових ресурсів, процес просторового розчленування виробництва був очевидним. Це відбулося за наявності сприятливих природних, економічних та соціальних умов на зазначених територіях для підвищення продуктивності праці [5].

Отже, сприятливе поєднання природних, трудових та інших умов і ресурсів на певних територіях країни призвело до закріплення за ними випуску окремих видів продукції, що позитивно позначилося на розвитку та поглибленні територіального поділу праці як джерела і стимулятора мотивації людей на конкретній території. Таким чином, за рахунок територіального поділу праці відбулося впорядкування розстановки продуктивних сил та їхніх елементів (предметів праці, засобів праці, робочої сили) на території країни, що призвело до зумовлення всього процесу розміщення виробництва.

Поступове зростання практичного інтересу до продуктивних сил у контексті особливостей, причин та методів їх розміщення, призвело до пожвавлення інтересу сучасної наукової спільноти до проблеми становлення та розгортання процесів розміщення виробництва на різних територіальних рівнях, вивчення характеру цих процесів та глибшому дослідженні сутності розміщення продуктивних сил і взаємозв'язків його головних складових елементів [12]. У сучасній науці розміщення продуктивних сил як систему чинників виробництва для забезпечення трансформації речовин природи відповідно до потреб людей, створення матеріальних та духовних благ і визначення зростання ефективності суспільної праці, зіставляють із динамічним процесом, тісно пов'язаним із природними, економічними та соціальними умовами економічних районів, зумовленим історично складеними особливостями територіального поділу праці.

Модель А. Вебера (1909), основою якої, як і у Й. Тюнена, виступає ізольована держава із забезпеченням виробництва природними ресурсами, що повинні бути сконцентровані навколо визначених ринкових центрів, також може бути використана в наші часи. Учений передбачив варіювання економічної вигідності окремих варіантів розміщення природних ресурсів («локалізованих матеріалів» та «повсюдних») залежно від процесів постачання та попиту й факторів розміщення (транспорту, робочої сили, агломерації чи дегломерації (розповсюдження)) об'єктів [9]. 
ПРОБЛЕМИ МЕНЕДЖМЕНТУ ТА РОЗВИТКУ ПРОДУКТИВНИХ СИЛ РЕГІОНУ

Варто зазначити, що теоретичне дослідження змістовної сутності продуктивних сил як економічної категорії, його наукової атрибуції, типології та концептуальних засад має значний еволюційний шлях розвитку. Проаналізуємо деякі найбільш часто згадувані в науковій літературі визначення цього терміна. Почнемо з обгрунтування категорії «продуктивні сили» К. Марксом. По суті, продуктивні сили в інтерпретації К. Маркса не що інше як перетворення продуктивних сил від найнижчих природних до найвищих загальних продуктивних сил через суспільні.

Отже, природні продуктивні сили К. Маркс розглядав і як стосовно природи самої людини, так і стосовно сил довкілля; суспільні продуктивні сили визначав як ті, що історично утворюються в процесі поділу, об'єднання праці та підйому суспільного характеру виробництва; загальні продуктивні сили ототожнював із формуванням їх за умови опанування індивідуумом сил природи за допомогою науки та науково-технічного прогресу [6; 7]. Науковець вважав головною компонентою продуктивних сил людину, а головним багатством суспільства - не тільки різноманітність здібностей, потреб індивідів, творчих обдарувань та рівень розвитку їхніх особистостей, але і їх виробничий досвід, знання, працелюбність і працездатність. Будучи актуальними й тепер, зазначені методологічні підходи виступають фундаментом сучасного тлумачення розвитку продуктивних сил.

Значущість цієї детермінанти продуктивних сил досліджували і з протилежних позицій. Так, уже в XV ст. почало закріплюватися твердження, що працелюбне населення першочергове багатство країни. Такої самої думки додержувалися В. Петті, назвавши «живі діючі сили» найбільшим елементом багатства, та А. Сміт, який вважав накопичені вигідні здібності всіх жителів (насамперед творчі) основним капіталом. Однак існували і протилежні погляди. Так, англійський економіст Т. Мальтус (1766-1834) визначав причиною злиденності зростаючу кількість населення. С. Сісмонді ввів твердження, що розвиток продуктивних сил відбувається за рахунок деградації індивідів з вигодою для капіталу. Культ «праця людей - головне джерело вартості» привів Д. Рікардо до певного переконання, що достовірні продуктивні сили це примножена потужність машин і техніки, яку він ототожнював із капіталом. Проте злиденного виробника він багатством не вважав. Звертаючись до визнання продуктивних сил, австрійський економіст Фрідріх Ліст (1789-1846) признавав головним багатством суспільства «розумовий капітал».

У працях більшості західних економістів переважаючою продуктивною силою визнано техніку та технологію з наданням першості поняттю «фактори виробництва». Вiдомий економіст М. Туган-Барановський (1865-1919) також підмінив категорію «продуктивні сили» поняттям «матеріальні фактори виробництва», які взаємозамінні між собою та допомагають розкрити зміст та сутність один одного, враховуючи більше вкладення евристичної цінності в поняття «продуктивні сили», більш точну відповідність принципам системно-структурного підходу (зокрема принципу цілісності) та можливості вивчення законів розвитку та функціонування продуктивних сил з характерними їм внутрішніми суперечностями.

Продукується думка, що поняття «продуктивні сили» є більш грунтовним, ніж «матеріальні фактори виробництва», оскільки перші є не лише матеріальними, але й духовними факторами виробництва (дух народу, ідеї людей, їхня психологія, національна самосвідомість). Формуючи суспільний спосіб виробництва, продуктивні сили в діалектичному єднанні з виробничими взаємозв'язками, відкривають у такий спосіб корисний шлях для дослідження процесу їх взаємодії, удосконалення та трансформації.

Отже, доцільність використання принципу суперечності як ядра діалектичного методу пізнання, повністю виправдана та підтверджена 3'ясуванням ступеня пристосування виробничих відносин рівню та характеру розвитку продуктивних сил для подальшого вивчення поступальності еволюційного розвитку. Намагання окремих науковців звузити предмет політичної економії лише дослідженням виробничих (еко- 
ПРОБЛЕМИ МЕНЕДЖМЕНТУ ТА РОЗВИТКУ ПРОДУКТИВНИХ СИЛ РЕГІОНУ

номічних) відносин є неправомірним і тотожне нехтуванню потреби вивчення людини як головної детермінанти продуктивних сил, їхніх потреб, інтересів, цілей, важливості людського фактору в сучасних умовах.

Неможливо обійти методологічний підхід і важливість внеску В. Вернадського (18631945) у визначення змісту та суті досліджуваного поняття. Новаторською можна вважати ідею академіка про природні продуктивні сили - сили природи, серед яких: продукти тваринного й рослинного світу, багатства надр, грунтів, джерела механічної енергії. Учений також вирізнив сили народу, які ще назвав «живі сили», які структурно пов'язав зі здатністю до роботи, чесністю, моральними та розумовими якостями, знаннями, талановитістю та ін. Визначаючи духовні сили основою національного багатства, він неупереджено стверджував, що з їх використанням народ здобуде собі необхідні сили природи [3].

Слід зазначити, що дискусії стосовно розуміння суті продуктивних сил як наукової категорії значно активізувались в останні десятиріччя. Так, деякі учені-економісти Ради по вивченню продуктивних сил України НАН України під продуктивними силами розуміють цілісність матеріальних, людських та інших силових елементів, неабиякою властивістю яких є утворююча дія (діяльність). Тобто сили, що безпосередньо беруть участь у продукуванні засобів, умов проживання людини та забезпечують розвиток самої людини та середовища іiї існування, і є продуктивними.

Як зазначають Д. Клиновий та Т. Пепа, економічна оцінка дії продуктивної сили враховує не тільки певну участь у створенні товарів чи послуг для задоволення потреб людей або суспільства, а й економічну доцільність діяльності зі створення вартості та додаткової вартості (прибутку) [4]. Інші вчені зосереджують свою увагу не стільки на кількісних ознаках продуктивних сил, скільки на якісних характеристиках, вважаючи, що «продуктивною $є$ така сила, яка в системі відносин між елементами відтворювального процесу забезпечує умови існування людини, iї соціального прогресу та самовідтворювальної здатності природи і суспільства» [8, с. 9]. Продуктивні сили характеризують як відкриту динамічну систему, яка постійно перебуває в русі, змінює при цьому форму, переходить від простішого рівня розвитку до більш складного.

Економічна енциклопедія «Політична економія» за редакцією А. Румянцева наводить дещо інше визначення: «Производительные силы - система личных, субъективных (человек) и технических (предметы) элементов, осуществляющих «обмен веществ» между человеком и природой в процессе общественного производства. Производительные силы выражают активное отношение людей к природе, заключающееся в материальном и духовном освоении, видоизменении, развитии и присвоении ее богатств» [10, с. 358]. Це розуміння підтримують відомі науковці, серед яких М. Хвесик, Л. Горбач, П. Пастушенко, які продуктивні сили розглядають як систему технічних та особистих елементів, завдяки яким у процесі суспільного виробництва здійснюється обмін між людиною та природою [14], та видатні вчені С. Дорогунцов, Ю. Пітюренко, Я. Олійник, Т. Заєць, С. Бандур та інші, які під продуктивними силами розуміють систему людських ресурсів та матеріальних елементів, відносин між ними, які в процесі здійснення економічної діяльності гарантують виробництво матеріальних благ та послуг для задоволення потреб суспільства [9, с. 14]. Зазначимо, що сучасні продуктивні сили характеризуються двома формами. Зокрема, перша - первинна, забезпечує здійснення розвитку духовно-соціальних продуктивних сил (являє собою безпосередньо органи матеріального виробничого процесу); а друга, відповідно, гарантує духовне оволодіння світом через розвиток знань, виробництво духовних багатств, науковий прогрес.

Отже, на основі глибинного вивчення та узагальнення існуючої термінології визначено, що продуктивні сили - це сукупність людських, матеріальних та інших силових елементів, з притаманною їм утворюючою дією, які беруть участь у процесі продукування засобів, забезпечення умов проживання людини, соціального прогресу та самовідтворювальної здатності природи й суспільства, але з урахуванням принципу оздоровлення екологічної ситуації, що вимагатиме екологізації свідомості, законодавства, управління. 
ПРОБЛЕМИ МЕНЕДЖМЕНТУ ТА РОЗВИТКУ ПРОДУКТИВНИХ СИЛ РЕГІОНУ

Економічна сутність категорії відтворення означає безперестанне відновлення виробництва товарів, послуг та духовних благ, на основі якого здійснюється відтворення сукупності елементів економічної системи - продуктивних сил, виробничих, організаційно-економічних та техніко-економічних відносин (або відносин економічної власності), а також господарського механізму [2, с. 223]. Отже, відтворення продуктивних сил доцільно розглядати як процес безперервного відновлення всіх факторів виробництва як природних ресурсів, робочої сили, так і засобів виробництва. Спрямованість відтворення характеризує динамічність цього процесу та безперервність руху соціальноекономічних потоків у часі.

Динамічний характер відтворення дає можливість вживати до національної економіки параметри її минулого, сучасного й майбутнього, тобто уявляти її поступовий розвиток через послідовну й закономірну зміну стану економіки. Доцільно розглядати відтворення як безперервне повторення процесів виробництва, розподілу, обміну та споживання, а відтворення продуктивних сил - як безперервний процес відновлення всіх факторів виробництва (людських та природних ресурсів, засобів виробництва).

Доречно в контексті поглиблення євроінтеграційних процесів дослідження процесів відтворення продуктивних сил провадити з урахуванням типу їх відтворення (рис. 1).

Так, визначення типу відтворення для економічних процесів має здійснюватися відповідно до характеру використання отриманого доходу та характеристики якісного змісту використання факторів виробництва.

Згідно з першим критерієм розрізняють:

- просте відтворення, яке характеризується відсутністю нагромадження, незмінністю запасу капіталу, сталістю економіки (обсяг заміщення капіталу, який вибув, дорівнює чистим інвестиціям), це означає, що весь обсяг виробленого продукту, зокрема й додаткового, суспільство витрачає на споживання, а саме виробництво відновлюється в тих самих обсягах і в тій самій кількості;

- розширене відтворення, яке характеризується зростаючими масштабами виробництва, отриманням доходу і для особистого споживання товаровиробника, і на купівлю додаткових виробничих ресурсів, що призведе до подальшого поновлювального виробництва в збільшеному розмірі, а відновлення виробництва в кожному новому відтворювальному циклі буде здійснюватися на більш високому (щодо попереднього) рівні, що в подальшому спричинить вищий ступінь споживання людей та зростання добробуту суспільства загалом;

- звужене (регресивне) відтворення, яке характеризується відновленням виробництва та споживанням у скорочених обсягах, характерне для країн у глибокій та тривалій соціально-економічній кризі, в обставинах швидкого та раптового руйнування єдиного економічного простору з розривом відтворювальних зв’язків [1].

Відповідно до другого критерію відокремлюють:

- екстенсивне відтворення - як процес примноження масштабів виробництва за рахунок включення додаткових ресурсів при збереженні технологічної основи, при цьому заходами екстенсифікації можуть бути: залучення обсягу інвестицій і капіталовкладень, освоєння нових ділянок землі, зростання чисельності працівників, збільшення робочого дня, зростання запасів сировини (не перспективний);

- інтенсивне відтворення - як процес збільшення обсягу виробництва за рахунок якісного оновлення технологій і техніки при таких заходах інтенсифікації: поліпшення техніки, результативне використання всіх ресурсів, економія матеріальних ресурсів, безперервна система підготовки робітничих кадрів, забезпечення трудової дисципліни, а також інтенсифікація управління, розвитку науки, інфраструктури;

- змішане відтворення - як процес збільшення масштабів виробництва за рахунок синергії процесів вдосконалення техніки і технології та підвищення кількості економічних ресурсів [1]. 


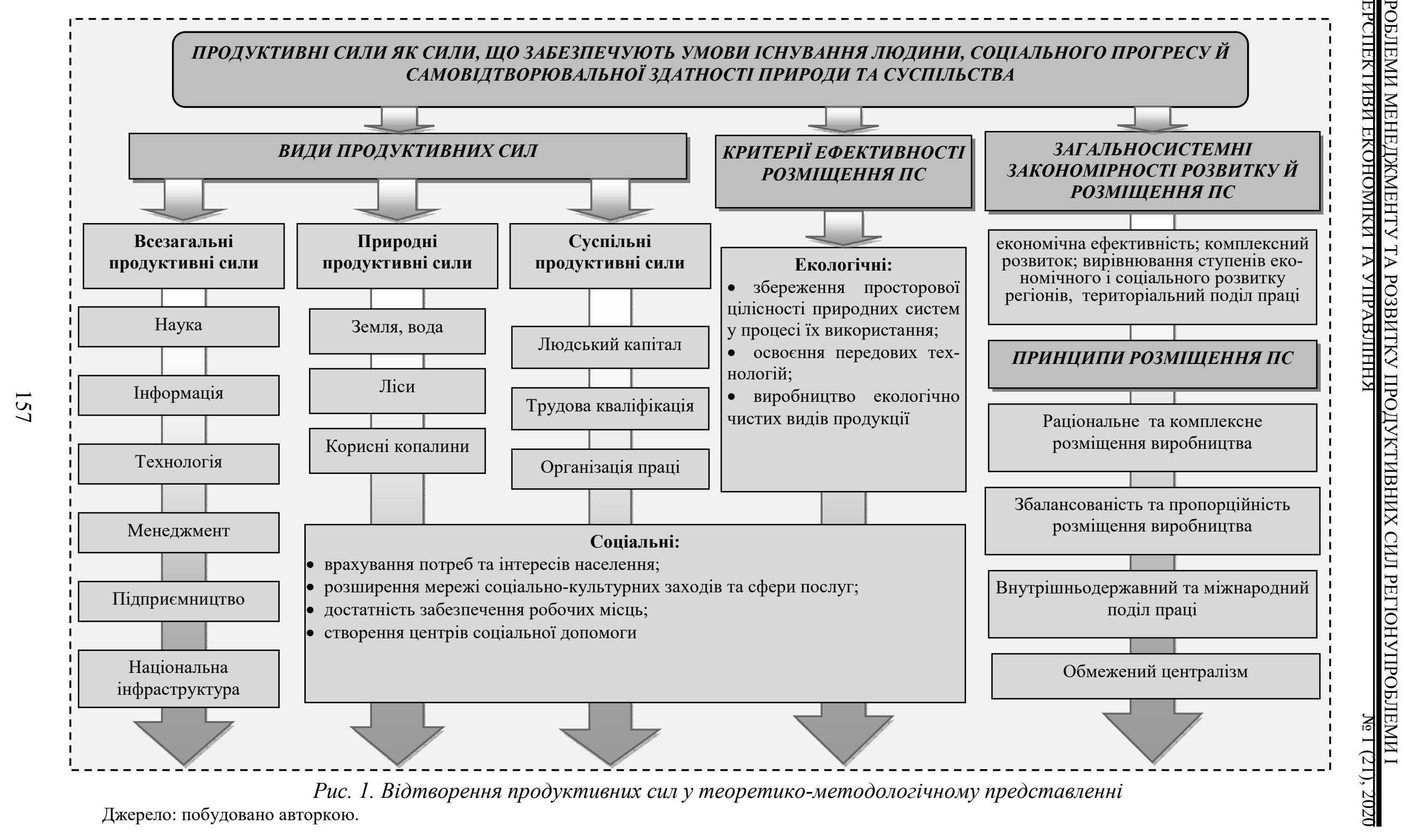


ПРОБЛЕМИ МЕНЕДЖМЕНТУ ТА РОЗВИТКУ ПРОДУКТИВНИХ СИЛ РЕГІОНУ

Процес глобалізації світової економіки створює потребу євроінтеграційного розвитку України, що, у свою чергу, сприяє радикальним перетворенням на шляху підвищення рівня соціально-економічного розвитку демократичної держави, закріпленню міжнародного образу країни як конкурентоспроможної i iнвестиційно-привабливої 3 одночасним вдосконаленням політичної системи та сфери захисту прав людини та передбачає відтворення продуктивних сил через відновлення всіх факторів виробництва. Беззаперечно, йдеться про обгрунтоване сполучення природних ресурсів, які значно вичерпані, робочої сили з притаманними їй критичними переходами від одного статусу зайнятості до іншого та засобів виробництва, технологічні схеми використання яких необхідно переглядати. Отже, оптимальне поєднання даних детермінант виробництва зумовлює необхідність пошуку механізмів стабілізації та розвитку процесів відтворення продуктивних сил.

Це вимагає розроблення концептуально нової стратегії модернізації продуктивних сил регіонів України в контексті розвитку зеленої економіки.

Усі інші проблеми, що пов'язані з дослідженням міжнародних сценаріїв розвитку зеленої економіки, інституціональних чинників якісно нового розвитку продуктивних сил, становлять перспективні напрями подальших наукових розвідок.

\section{Список використаних джерел}

1. Бойченко Е. Б. Діагностика відтворення продуктивних сил в контексті розвитку регіонального соціуму : дис. ... д-ра екон. наук : 08.00.05 / Ін-т економіко-прав. досл. Київ, 2016. 509 с.

2. Економічна енциклопедія : у 3 т. Т. 3 / ред. С. В. Мочерний. Київ : Видавничий центр «Академія», 2002.952 с.

3. Заблоцький Б. Розміщення продуктивних сил України: Національна макроекономіка : посібник. Київ : Академвидав, 2002. 367 с.

4. Клиновий Д. В., Пепа Т. В. Розміщення продуктивних сил та регіональна економіка України : навчальний посібник / за наук. ред. Л. Г. Чернюк. Київ : Центр навчальної літератури, 2006. $728 \mathrm{c}$.

5. Курочкін Г. Ф. Розміщення продуктивних сил і регіональна економіка : навч. посіб. Київ : Національна академія управління, 2004. 272 с.

6. Маркс К. Капітал. Критика політичної економії. Маркс К., Енгельс Ф. Твори : пер. 3 другого рос. видання. Київ : Держполітвидав УРСР, 1963. Т. 23. 847 с.

7. Маркс К. Твори : в 50 т. Т. 46. Ч. 2. Жовтень 1857 р. - березень 1861 р. 2-ге вид. Київ : Політвидав, 1982. $577 \mathrm{c}$.

8. Продуктивні сили економічних районів України / Б. М. Данилишин та ін. Київ : НІЧЛАВА, 2000. $520 \mathrm{c}$.

9. Розміщення продуктивних сил України : навч.-метод. посібник для самост. вивч. дисц. / С. І. Дорогунцов та ін. Київ : КНЕУ, 2000. 364 с.

10. Румянцев А. М. Политическая экономия : учебник : в 2 т. 5-е изд., доп. Москва : Политиздат, 1982. Том 1: Капиталистический способ производства / Г. А. Козлов [и др.]; ред. : А. М. Румянцев, Г. А. Козлов. 560 с.

11. Соціально-економічний потенціал сталого розвитку України та ії регіонів: національна доповідь / за ред. акад. НАН України Е. М. Лібанової, акад. НААН України М. А. Хвесика. Київ : ДУ ІЕПСР НАН України, 2014. 776 с.

12. Стеченко Д. М. Розміщення продуктивних сил і регіоналістика : підручник. Київ : Вікар, 2006. $396 \mathrm{c}$.

13. Сторонянська I. 3. Організаційно-економічні основи міжрегіонального співробітництва прикордонного регіону (на прикладі Західного регіону України) : автореф. дис. ... канд. екон. наук : спец. 08.10.01 «Розміщення продуктивних сил і регіональна економіка» / Нац. акад. наук України, Ін-т регіон. дослідж. Львів, 2002. 19 с.

14. Хвесик М. А., Горбач Л. М., Пастушенко П. П. Розміщення продуктивних сил та регіональна економіка : навч. посіб. Київ : Кондор, 2009. 344 с.

15. Anishchenko V., Marhasova V., Fedorenko A., Puzyrov M., Ivankov O. Ensuring environmental safety via waste management. Journal of Security and Sustainability Issues. 2019. Vol. 8(3). P. 507-519. 
ПРОБЛЕМИ МЕНЕДЖМЕНТУ ТА РОЗВИТКУ ПРОДУКТИВНИХ СИЛ РЕГІОНУ

16. Burlutskiy S. V., Burlutska S. V., Marhasova V. G., Sakun O. S. (2019). The relationship between short-term fluctuations and stages of economic cycle: The case of Ukraine. Espacios. 2019. Vol. 40, No. 10. URL: http://www.revistaespacios.com/a19v40n10/a19v40n10p10.pdf.

\section{References}

1. Boychenko, E. B. (2016). Diahnostyka vidtvorennia produktyvnykh syl v konteksti rozvytku rehionalnoho sotsiumu [Diagnosis of reproduction of productive forces in the context of regional society development]. (Candidate's theses). Development of productive forces and regional economy, Institute for Economic and Legal Research, Kyiv [in Ukrainian].

2. Mochernyi, S. V. (2002). Ekonomichna entsyklopediia [Economic Encyclopedia]. Kyiv: Vydavnychyi tsentr "Akademiia" [in Ukrainian].

3. Zablotskyi, B. (2002). Rozmishchennia produktyvnykh syl Ukrayiny [The Deployment of Productive Forces Ukraine]. Kyiv: Akademvydav [in Ukrainian].

4. Klynovyi, D. V., Pepa, T. V. (2006). Rozmishchennia produktyvnykh syl i rehionalna ekonomika [The Deployment of Productive Forces and the Regional Economy]. Kyiv: Tsentr navchalnoi literatury [in Ukrainian].

5. Kurochkin, G. F. (2004). Rozmishchennia produktyvnykh syl i rehionalna ekonomika [The Deployment of Productive Forces and the Regional Economy]. Kyiv: Natsionalna akademiia upravlinnia [in Ukrainian].

6. Marks, K., Iengels, F. (1963). Kapital. Krytyka politychnoi ekonomii [Capital. Criticism of political economy]. In K. Marks, F. Iengels, Tvory [Writings]. (Vol. 23). Kyiv: Derzhavne politychne vydavnytstvo URSR [in Ukrainian].

7. Marks, K., Iengels, F. (1982). Tvory [Writings] ( $2^{\text {nd }}$ ed.). Kyiv: Politychne vydavnytstvo [in Ukrainian].

8. Danylyshyn, B. M., Chernyuk, L. H., Horska O. V. (2000). Produktyvni syly ekonomichnykh raioniv Ukrayny [Productive forces of economic regions of Ukraine]. Kyiv: NICHLAVA [in Ukrainian].

9. Dorohuntsov, S. I., Pitiurenko, Yu. I., Oliinyk, Ya. B. (2000). Rozmischennia produktyvnykh syl Ukrainy [Location of productive forces of Ukraine]. Kyiv: KNEU [in Ukrainian].

10. Rumyantsev, A. M. (1982). Politicheskaia ekonomiia [Political Economy]. (5rd ed.). Moscow: Politizdat [in Russian].

11. Libanova, E. M., Khvesyk, M. A. (Eds.). (2014). Sotsialno-ekonomichnyi potentsial staloho rozvytku Ukrayiny ta yii rehioniv: natsionalna dopovid [Socio-economic potential of sustainable development of Ukraine and its regions: a national report]. Kyiv: DU IEPSR NAN [in Ukrainian].

12. Stechenko, D. M. (2006). Rozmishchennia produktyvnykh syl i rehionalna ekonomika [The Deployment of Productive Forces and the Regional Economy]. Kyiv: Vikar [in Ukrainian].

13. Storonyanska, I. Z. (2002). Orhanizatsiino-ekonomichni osnovy mizhrehionalnoho spivrobitnytstva prykordonnoho rehionu (na prykladi Zakhidnoho rehionu Ukrainy) [Organizational and economic foundations of cross-border cooperation in the border region (for example, the Western region of Ukraine)]. (Candidate's theses). Productive deployment and the regional economy, Institute for Regional Studies, Lviv [in Ukrainian].

14. Khvesyk, M. A. Horbach, L. M., Pastushenko, P. P. (2009). Rozmischennia produktyvnykh syl ta rehionalna ekonomika [Rozmischennia produktyvnykh syl Ukrainy]. Kyiv: Kondor [in Ukrainian].

15. Anishchenko, V., Marhasova, V., Fedorenko, A., Puzyrov, M., Ivankov, O. (2019). Ensuring environmental safety via waste management. Journal of Security and Sustainability Issues, 8(3), 507-519.

16. Burlutskiy, S. V., Burlutska, S. V., Marhasova, V. G., Sakun, O. S. (2019). The relationship between short-term fluctuations and stages of economic cycle: The case of Ukraine. Espacios, 40 (10). Retrieved from http://www.revistaespacios.com/a19v40n10/a19v40n10p10.pdf.

Дідовець Аліна Сергіївна - аспірантка кафедри менеджменту та державної служби, Чернігівський національний технологічний університет (вул. Шевченка, 95, м. Чернігів, 14035, Україна).

Дидовец Алина Сергеевна - аспирантка кафедры менеджмента и государственной службы, Черниговский национальный технологический университет (ул. Шевченко, 95, г. Чернигов, 14035, Украина).

Didovets Alina - PhD student of the Department of Management and Civil Service, Chernihiv National University

of Technology (95 Shevchenka Str., 14035 Chernihiv, Ukraine).

E-mail: alina777petrovskaya@gmaii.com

ORCID: https://orcid.org/0000-0003-4680-6926

ResearcherID: C-1303-2017

Дідовець А. Теоретико-методологічні аспекти відтворення продуктивних сил в умовах євроінтеграції. Проблеми $і$ перспективи економіки та управління. 2020. № 1 (21). С. 151-159. 